\title{
Domestic workers regulation
}

\section{Ana Virginia Moreira Gomes}

\section{(2) OpenEdition}

\section{Journals}

Electronic version

URL: https://journals.openedition.org/rdctss/1834

DOI: $10.4000 /$ rdctss. 1834

ISSN: 2262-9815

\section{Publisher}

Centre de droit comparé du travail et de la sécurité sociale

\section{Printed version}

Date of publication: 1 December 2018

Number of pages: 224-227

ISSN: $2117-4350$

\section{Electronic reference}

Ana Virginia Moreira Gomes, "Domestic workers regulation", Revue de droit comparé du travail et de la sécurité sociale [Online], 4 | 2018, Online since 01 November 2021, connection on 15 November 2021 URL: http://journals.openedition.org/rdctss/1834 ; DOI: https://doi.org/10.4000/rdctss.1834

\section{(c) (i) (9)}

Revue de droit comparé du travail et de la sécurité sociale est mise à disposition selon les termes de la Licence Creative Commons Attribution - Pas d'Utilisation Commerciale - Pas de Modification 4.0 International. 


\title{
ANA VIRGINIA MOREIRA GOMES
}

\author{
FORTALEZA UNIVERSITY
}

\section{DOMESTIC WORKERS REGULATION}

Brazil ratified ILO Convention 189 on Decent Work for Domestic Workers on January 31,2018 . By doing so, Brazil became the $25^{\text {th }}$ ILO member state and the $14^{\text {th }}$ ILO member state in the Americas to ratify Convention 189.

The ratification of Convention 189 represents a milestone in a regulatory process in Brazil towards equality of rights between domestic workers and other workers that began with the promulgation of the 1988 Federal Constitution.

The regulation of domestic work by labor law in Brazil started in 1972 with the enactment of the domestic labor law - Law \# 5.859. ${ }^{1}$ This law guaranteed to domestic workers some of the labor rights already accorded to other workers: annotated professional card, paid annual leave of 20 working days and inclusion in the social security scheme. While this was considered progress, it did not give domestic workers a status equal to other workers.

In 1988, the Federal Constitution started to protect rights of domestic workers under the law, guaranteeing domestic workers some of the fundamental labor rights accorded to all other workers. ${ }^{2}$ This inclusion, as well as the first law of 1972, were the result of a constant struggle of the domestic workers' movement. Domestic workers have been outside the official trade union system and ignored by traditional syndicalism. Despite facing immense difficulties, these unions, supported by the feminist and Afro-Brazilian movements, succeeded in ensuring that domestic workers acquire some of the fundamental rights granted to all other workers. ${ }^{3}$ The original text of the 1988 Constitution had important flaws concerning the protection of domestic work. For example, it guaranteed some employment

1 Before the promulgation of the Law $n^{\circ} 5.859 / 1972$, there were scattered laws that either aimed at controlling domestic work or provided for individual rights, often depending on the will of the employer. Among those, we highlight the Decree $n^{\circ} 3,087 / 60$, which guaranteed domestic workers the right to join the social security system, initially as voluntary members, and in 1973, as mandatory members; and Law $n^{\circ} 5,316 / 67$, which extended to domestic workers the right to insurance for occupational accidents.

2 The fundamental labour rights originally guaranteed by the Federal Constitution to domestic workers were: minimum wage and the irreducibility of wages, unless otherwise provided by agreement or collective agreement; weekly paid rest, preferably on Sundays; the thirteenth salary; the enjoyment of paid annual leave at least one third more than the normal salary; the leave to pregnant women, without prejudice to employment and salary of 120 days; paternity leave; the prior notice proportional to the length of service with at least 30 days, in accordance with the law; retirement and integration into Social Security.

3 Article 7 of the 1988 Constitution guarantees to domestic workers ten of the twenty nine fundamental labour rights guaranteed to all workers: minimum wage; irreducibility of wage; annual bonus equal to one month's salary; paid weekly leave, preferably on Sundays; annual paid vacation with remuneration at least one third higher than the normal wage; 120 days paid maternity leave; five days paid paternity leave; notice of dismissal; as well as of integration in the social security system. 
rights, but no right to limited hours of work; it guaranteed freedom of association, but no right to collective bargaining.

The legal inclusion process started by the Federal Constitution of 1988, however, was a slow, but so far, irreversible process. In 2006, another important regulatory breakthrough was achieved with Law $n^{\circ} 11.324 / 2006$, which expanded the protection granted by law $n^{\circ} 5.859$ from 1972. Law $n^{\circ} 11.324 / 2006$ guaranteed the right to thirty days of paid vacation, employment protection for pregnant workers, paid legal holidays, and the prohibition of a wage discount in case of supply of meals, housing and hygienic products by the employer. Another important development came with federal decree $n^{\circ} 6481$ in 2008 that included domestic child labour among the worst forms of child labour and prohibited domestic work for workers under the age of eighteen years old. ${ }^{4}$

In 2013, a Constitutional Amendment, n72/2013, was approved, recognizing to domestic workers all fundamental labour rights guaranteed to a typical employee, such as indemnization in case of dismissal without cause, unemployment insurance, extra pay for night-shift work, family bonus, overtime pay, limited hours of work, severance pay indemnity fund system (FGTS), and occupational accident insurance. In 2015, Law n¹50 regulated the exercise of the new recognized rights, regulating the domestic work contract as well as the payment of social security and tax contributions. Among the new rights guaranteed, we highlight the limits on work hours and the protection against dismissal without cause. These two rights have the potential to correct two extremely unfair situations historically experienced by domestic workers: very long working days, especially in the case of live-in domestic workers, and the absence of any legal protection in the case of dismissal, often after a period of almost a lifetime working for one family.

An essential aspect of the new regulation concerns the possible impact of the new rights on the labor market. We know that the social and economic context of domestic work in the 1990s and 2000s changed in a positive way. ${ }^{5}$ This development happened, in spite of the still extremely large number of domestic workers - 6.2 million domestic workers who represent $10 \%$ of the labour force in the country ${ }^{6}$ - and of working conditions lower than those experienced by other workers, specially concerning wages and working hours. Exactly which changes are consequences of the new regulation is not precisely clear. For example, the probability of domestic employees (not self-employed domestic workers) having a formal contract and reduced working hours has increased. ${ }^{7}$ Costa et al suggest that the Constitutional Amendment $n^{\circ} 72$ might have had a significant effect on these

4 This decree creates the Brazilian list of worst forms of child labour in accordance with ILO Convention 182 ratified by Brazil.

5 On one side, it is true that, at least, in part of the 2000s the economy was thriving. On the other, though, it can be argued that regulation went through periods of economic crisis in the 1990s and economic prosperity in the 2000s in a scenario of slow and steady improvement in the working conditions of domestic workers.

6 Instituto Brasileiro de Geografia e Estatísitca, Pesquisa Nacional por Amostra de Domicílio PNAD, 2017, ftp://ftp.ibge.gov.br/Trabalho e Rendimento/Pesquisa Nacional por Amostra de Domicilios continua/Trimestral/Fasciculos Indicadores IBGE/pnadc 201702 trimestre caderno. pdf

7 Costa, Joana Simões de Melo et al. Efeitos da Ampliação dos Direitos Trabalhistas sobre as Condições de Trabalho das Empregadas Domésticas. IPEA, mercado de trabalho | 60 | abr. 2016, 59-62, http://www.ipea.gov.br/portal/index.php?option=com content\&view=article\&id=28822 
outcomes although the analysis to prove causality has not been reported yet. Another two positive labour market developments are the growth of formal jobs and income, at least until the beginning of the current economic crisis in 2014. Contrary to the common sense prevalent in policy discussions about the regulation of domestic work, informality has declined in the main part of the period since regulation began to take shape (from 1988 until now). ${ }^{8}$ The increase in formalization, together with the increases in minimum wage, were linked to the growth of the average income of domestic workers in the last two decades of approximately $64 \%{ }^{9}$

In addition to the concrete effects of changes in the law, the process towards the equalization of rights and the changes in the social and economic conditions of domestic workers in Brazil have the potential to converge. This would be a significant development in addressing the problem of inequality in the country centred around colour and gender discrimination.

The two types of discrimination are intrinsically linked to domestic work in Brazil for historical reasons (ILO, 2010, p.19). The majority of domestic workers are women (5.9 out of 6.2 million), roughly $14 \%$ of the female workforce in Brazi ${ }^{10}$. Domestic work is still the second most common job for women ( $92 \%$ of domestic workers are women), and one of the main jobs for African-Brazilians (62\% of domestic workers are African-Brazilians). ${ }^{11}$

The guarantee of labour rights, on an equal standard as accorded to other workers, is the first step in recognizing the social and economic value of domestic work; however, if the public policies do not recognize the linkage between domestic work, color discrimination and division of family responsibilities, those new labour rights will keep facing strong obstacles in becoming effective.

An army of low income and low educated women subsidizes the work of care so middleclass women can go out for work. Since the performance of domestic services, whether paid or unpaid, is a responsibility primarily of women, the care for the family is a problem solved privately among women. The abundant supply of domestic workers despite very challenging conditions of employment, suggests a significant lack of opportunities for women, especially black women. It is one more element that contributes to informality and devaluation of domestic work. Domestic work is still the main occupation among black women (17.7\% of black women were domestic workers). ${ }^{12}$

There has been a slow decline in the number of domestic workers in the country: from 1995 to 2015 , the size of domestic workforce went from $17.3 \%$ to $14.3 \%$ of all women

8 From 1995 to 2015 there was a $12.6 \%$ points increase in the formalization of work, raising the share of formal domestic workers from $17,8 \%$ to $30.4 \%$. Pinheiro, supra, 17; IPEA. Retrato das Desigualdades de Gênero e Raça, 2017. http://www.ipea.gov.br/portal/images/stories/ PDFs/170306 retrato das desigualdades de genero raca.pdf

9 Despite the growth, the average income in 2015 is lower than the minimum wage ( $R 739$ versus R \$ 788). IPEA,2017, supra.

10 Departamento Intersindical de Estatística e Estudo Socioeconômico - DIEESE. O emprego doméstico no Brasil, n 68, ago./2013,

http://www.dieese.org.br/estudosetorial/2013/estPesq68empregoDomestico.pdf

11 IBGE, 2017, supra.

12 IPEA, 2017, supra. 
in employment. ${ }^{13}$ An important indicator of an increase in educational and economic opportunities for young women is that the domestic workforce is aging.. ${ }^{14}$ Together with the protection of the labor law, public policies, which permit occupational migration, allowing women to leave domestic employment or enter into labor market, are essential to making domestic work an activity that is not marked by precariousness and vulnerability.

In this scenario, the approval of ILO Convention 189, in the case of Brazil, consolidates the process of legal inclusion of domestic labor initiated at the end of the 1980s. The ratification of the Convention 189, however, has the power to confer even greater legitimacy to this process, as closing political discussions about the appropriateness of giving this group of workers labor rights.

From a formal perspective, Brazilian law is in line with the terms of the 189 Convention, as the Federal Constitution guarantees to domestic workers fundamental rights and the complementary law 150/2015, employment rights. Domestic workers trade unions are officially recognized and in June 2013, the first collective agreement on domestic work was signed in São Paulo between the Union of Employers and Domestic Workers of Greater São Paulo (SINDOMESTICA) and Union of Domestic Employers of the State of São Paulo (SEDESP).

From a material perspective, the laws are still not effective enough. The average income in domestic work is still below the minimum wage and informality rates are higher than in other activities. ${ }^{15}$ The challenge for the ILO and Brazil, therefore, is to focus on creating mechanisms to improve the socio-economic conditions of the groups most vulnerable to informal and precarious domestic employment. Only then can a legislation that protects the dignity of domestic workers, be made effective.

13 IPEA,_2017, supra.

14 Among black women however, the transition from domestic work to other activities has been occurring at a slower pace. IPEA,_2017, supra, 3 and 16.

15 Only $30 \%$ of workers are formal Fontoura, Natália; Lima Júnior, Antônio Teixeira; Cherfem, Carolina Orquiza. PNAD 2014 - Alterações recentes no mundo do trabalho, segundo marcadores de gênero e raça. In: Calixtre, André; VAZ, Fábio (Org.). PNAD 2014 - Breves Análises. Brasília: 2015, http://www.ipea.gov.br/portal/index.php?option=com content\&view=article\&id=26999|PEA, 2017, supra. 